Ida Rahmawati

1810111320003

Ida.rahma.ir050400@gmail.com

Tugas Artikel Pembelajaran IPS

\title{
Pendidikan Karakter Dalam Pembelajaran IPS
}

\section{PENDAHULUAN}

Dalam perkembangan masyarakat semakin kedepan maju seiring dengan berkembangnya teknolog dan informasi dalam era globalisasi ini, perkembangan arus globalisasi ini membawa dampak negatif dalam kehidupan masyarakat yakni semakin lunturnya nilai-nilai karakter dikalangan para generasi muda Indonesia.Lunturnya etika dan budi pekerti,korupsi kian merajalela,banyaknya pelanggaran HAM,setra banyak kkerasan terhadap anak perempuan.Melihat kenyataan yang terjadi di masyarakat,hal ini dapat mengotori karakter bangsa.Apabila hal ini dibiarkan,maka bangsa indonesia akan kehilangan jati diri dan karakter bangsa.Tentu saja dalam hal ini tidak ingin menghendaki kehilangan jati diri dan karakter bangsa yang sangat bermartabat.

Kaarakter merupakan salah satu dari misi pembangunan nasional seperti tertuang dalam UU RI.No 17 Tahun 2007 menuangkan karakter yakni :"terwujudnya karakter bangsa yang tangguh,kompetitif,berakhlak mulia,dan bermoral berdasarkan pancasila,yang dicirikan dengan watak dan perilaku manusia dan masyarakat Indonesia yang beragam,beriman dan bertakwa kepada Tuhan Yang Maha Es,bebudi luhur,bertoleran,bergotong royong,berjiwa Pentingnya karakter,berjiwa patriotisme, berkembang dinamis, dan berorientasi ipteks (Udin.S.Winataputra,2010:2).Pentingnya pendidikan karakter tertuang dalam tujuan pendidikan nasioanal yang tercantum pada UU.No 20 Tahun 2003 tentang Sisdiknas,pasal 3,yang dijelaskan bahwa pendidikan nasional berfungsi mengembangkan kemampuan dan membentuk watak serta peradaban bangsa yang bermartabat untuk mencerdaskan kehidupan bangsa,serta bertujuan untuk mengembangkan potensi peserta didik agar menjadi manusia yang beriman dan bertakwa kepada Tuhan Yang Maha Esa,berakhlak mulia,sehat,berilmu,cakap, 
kreatif,mandiri dan mandiri dan menjadi warga negara yang demokratis serta bertanggung jawab.

Penerapan pendidikan karakter bagi semua tingkat satuan pendidikan mulai dari sekolah dasar hingga perguruan tinggi dilaksanakan melalaui semua mata pelajaran,salah satunya dalam Ilmu Pengetahuan Sosial (IPS).Melalaui pendidikan karakter IPS diharapkan anak didik dapat menguasi ilmu sosial,sehinngga anak didik siap untuk hidup dan menghadapi gejala-gejala sosial dan permasalahannya dengan tetap mempertahankan budi pekerti yang luhur.

\section{KAJIAN TEORI}

\section{Hakikat Pendidikan Karakter}

Pendidikan karakter adalah upaya yang dilakukan dengan sengaja untuk mengembangkan karakter yang baik (good character) berlandaskan kebijakan-kebijakan inti (core virtues) yang secara objektif baik bagi individu maupun masyarakat (Sudarmi,2012).Proses pendidikan karakter didasarkan secara totalitas pada kemampuan atau potensi yang dimiliki oleh setiap individu mencakup kognitif,afektif,dan psikomotorik serta fungsi totalitas sosiokultular pada konteks interaksi dalam keluarga,satuan pendidikan,serta masyarakat.Sebelum memasuki implementasi pendidikan karakter,maka harus diterapkannya terlebih dahulu sebelas prinsip pendidikan karakter (Saptono,2011).

Meliputi : (1) Sekolah harus berkomitmen pada nilai-nilai etis inti; (2) Karakter harus dipahami secara utuh,mencakup pengetahuan atau pemikiran perasaan,dan tindakan; (3) Sekolah harus bersifat proaktif dan bertindak sistematis dalam pembelajaran karakter dan tidak sekedar menunggu datangnya kesempatan; (4) Sekolah harus membangun suasana saling memperhatikan satu sama lain dan menjadi dunia keci (mikokosmos) mengenai masyarakat yang saling peduli; (5) Kesempatan untuk mempraktikkan tindakan tindakan moral harus bervariasi dan 
tersedia bagi semua; (6) Studi akademis harus menajdi hal utama; (7) Sekolah perlu mengembangkan caracara meningkatkan motivasi intrinsik siswa yang mencakup nilai-nilai inti; (8) Sekolah perlu bekerja bersama dan mendialogkan norma mengenai pendidikan karakter; (9) Guru dan siswa harus berbagi dalam kepemimpinan moral sekolah; (10) Orang tua dan masyarakat harus menjadi rekan kerja dalam pendidikan karakter di sekolah; (11) Harus dilakukan evaluasi mengenai efektivitas pendidikan karakter di sekolah, terutama terhadap guru dan kayawan serta siswa.

Pada dasarnya sebelum mengajarkan pendidikan karakter pada peserta siswa,perlu diketahui bahwa pendidikan karakter telah termaktub dalam pendidikan berbicara,berperilaku,kebiasaan,dan harapan-harapan pada potensi siswa.Sehingga dengan demikian perlunya dikenal terlbih dahulu apakah karakter itu dan bagaimana memahami karakter siswa.Menurut Sudarmi (2012) Karakter merupakan sebuah keyakinan terhadap suatu hal yang belum dapat dipastikan kebenaran maupun ketidak benaran berdasarkan pandangan masyarakat sekitar.Pada dasarnya pendidikan karakter bukan sekedar mengaajarkan mana yang lebih benar dan mana yang salah,lebih dari itu,pendidikan karakter menanamkan kebiasaan (habituation) tentang mana yang baik sehingga siswa menjadi paham (kognitif) tentang mana yang benar dan salah ,maupun merasakan (afektif) nilai baik dan biasanya melakukannya (psikomotorik).

Dengan kata lain pendidikan karakter yang baik harus melibatkan bukan saja aspek pengetahuan yang baik (moral knowing), akan tetapi juga "merasakan dengan baik atau loving good (moral feeling), dan perilaku yang baik ( moral action).Hal ini pendidikan karaker lebih menekankan pada habitat atau kebiasaan yang terus menerus dipraktikan dan dilakukan (Kemendiknas,2011).

\section{Pembelajaran IPS}

Peran IPS di sekolah sebagai kebutuhan masyarakat yang tengah berkembang menuju masyarajat sejahtera. Ilmu Pengetahuan Sosial 
(IPS) sebagai bagian integral dari kurikulum pembelajaran di persekolahan, selayaknya disampaikan secara menarik dan penuh makna dengan memadukan seluruh komponen pembelajaran secara efektif. IPS sebagai disiplin ilmu yang memiliki sensitivitas tinggi terhadap dinamika perkembangan masyarakat. Menurut Numan Sumatri (2004: 44). IPS merupakan gabungan dari berbagai displin ilmu, bukan hanya ilmu-ilmu sosial melainkan juga dari humanitis, matematika dan ilmu-ilmu alam bahka agama. Hal ini dapat disimpulkan bahwa materi kajian IPS merupakan perpaduan dari berbagai ilmu-ilmu sosial, sehingga materi IPS harus didesaian secara terpadu agar lebih bermakna dan kontekstual. Materi IPS juga dikaitkan dengan masalah-masalah sosial yang disesuaikan dengan perkembangan masyarakat. Tujuannya yakni untuk mengembangkan peserta didik agar memiliki kepekaan terhadap masalah sosial yang terjadi di masyarakat, memiliki sikap mentak terhadap perbaikan segala ketimpangan yang terjadi, dan terampil dalam mengatasi setiap masalah yang terjadi sehari-hari.

Materi kajian IPS juga harus didukung pembelajaran yang sesuai dengan karakteristik peserta didik. Pembelajaran IPS adalah suatu sistem pendidikan yang terdiri dari peserta didik, media belajar, fasilitas belajar, dan sumber belajar yang bertujuan untuk membuat peserta didik memahami berbagai integritas dari berbagai Ilmu sosial. Pembeajaran IPS melibatkan peserta didik untuk aktif. Disini peran guru sangat penting untuk memilih media belajar dan mefasilitasi peserta didik, serta memanfaatkan sumber-sumber belajar yang beragam yang ada di dalam lingkungan sekolah maupun diluar sekolah. Pembelajaran IPS mengutamakan peserta didik untuk menempatkan diri pada situasi yang mampu mengkontruksi pemikirannya dan mampu mengekpresikan dirinya secara tepat di lingkungan peserta didik berada. Melihat karakteristik pembelajaran IPS diatas menunjukkan bahwa pembelajaran IPS umumnya bertujuan 
agar peserta didik memiliki kemampuan untuk mengenalkan konsepkonsep yang berkaitan dengan kehidupan masyarakat agar peserta didik dapat berpikir logis, kritis, memiliki rasa ingin tahu dalam memecahkan masalah. Peserta didik diharapkan dapat bersikap arif, santun dan tidak emosional dalam memahami, menyikapi dan ikut serta dalam memecahkan berbagai persoalan sosial, memiliki kepekaan sosial dan rasa empati. Pembelajaran IPS juga diharapkan dapat melatih peserta didik untuk mengembangkan kemampuan dan keterampilan seperti berkomunikasi, beradaptasi, bersinergi, bekerja sama, bahkan berkompetisi sesuai dengan adab dan norma-norma yang ada.

\section{Kesimpulan}

Perkembangan teknologi informasi dan komunikasi yang sedemikian cepat dalam era globalisasi, menambah semakin cepat perkembangan kehidupan sosial beserta dampak yang mengiringinya. Arus globalisasi juga membawa dampak negatif dalam kehidupan masyarakat yakni semakin lunturnya nilai-nilai karakter dikalangan para generasi muda Indonesia. Pesertadidik adalah generasi muda penerus bangsa, sehingga perlu dididik dan dibina agar menjadi warga negara yang memahami dan memiliki kesadaran terhadap hak dan kewajibannya. Dalam konteks fenomena globalisasi, pendidikan Ilmu Pengatahuan Sosial perlu mengembangkan pembelajaran yang mampu mengakomodasikan semua kecenderungan yang terbawa dalam proses globalisasi itu.

Pembelajaran IPS memiliki peran penting dalam pembentukan karakter bangsa. Sebab pembelajaran IPS memiliki kesamaan dengan pendidikan nilai atau pendidikan karakter yang masing-masing bertujuan untuk menjadikan peserta didik sebagai warga negara yang baik, dan peduli terhadap masalah sosial dan lingkungannya, serta memiliki rasa kebangsaan yang tinggi. Dalam upaya pembentukan 
karakter peserta didik di sekolah melalui pembelajaran IPS paling tidak mencakup 4 yang harus dilakukan yakni kurikulum, materi, guru,dan proses pembelajaran. Kurikulum di sekolah harus mampu mengembangkan pengetahuan, keterampilan, sikap, nilai, dan moral. Materi IPS disusun dan dirancang untuk mengenalkan konsep-konsep yang berkaitan dengan kehidupan masyarakat serta mengembangkan pengetahuan, pemahaman, dan kemampuan terhadap kondisi sosial di masyarakat. Untuk itu, guru IPS harus berpegang pada 5 prinsip pembelajaran yaitu: bermakna (meaningful), terpadu (integrative), menantang (challenging), aktif (active), dan berbasis nilai (value based), sehingga pembelajaran IPS tercipta suasana belajar yang kondusif dan produktif untuk memberikan pengalaman belajar kepada peserta didik dengan melibatkan peserta didik secara proaktif dan interaktif baik dalam proses pembelajaran di kelas maupun di luar kelas. Peserta didik diberi pengalaman belajar yang bermakna (meaningful learning) dalam membentuk dan mengembangkan karakter peserta didik.

\section{Daftar Pustaka}

Abbas, E. W. (2013). Mewacanakan Pendidikan IPS. Mewacanakan Pendidikan IPS.

Herry Porda Nugroho Putro, E. A. (2021). PENGEMBANGAN MODEL PEMBELAJARAN ILMU PENGETAHUAN SOSIAL (IPS) UNTUK PENGURANGAN RESIKO ENCANA DI SEKOLAH PADA DAERAH RAWAN BENCANA DI LINGKUNGAN LAHAN BASAH KABUPATEN BANJAR. Prosiding Seminar Nasional Lingkungan Lahan Basah Volume 6 Nomor 1 April 2021, 1-4. 
Kementerian Pendidikan Nasional. 2011. Pengembangan Pendidikan Budaya dan Karakter Bangsa. Puskur. Jakarta.

Numan Sumatri. 2011. Mengagasa Pembelajaran Pendidikan IPS. Bandung: Remaja Rosdakarya

Saptono. 2011. Dimensi-dimensi Pendidikan Karakter. Wawasan, Strategi, dan Langkah Praktis. Jakarta: Esensi Elangga Group.

Sri Sudarmi.2012 : Muatan Pendidikan Karakter Pada Pembelajaran Ilmu Pengetahuan Sosial di Sekolah Dasar.Jurnal Sekolah dasar Volume 21 Nomor 2 November 2012.

Winataputra, Udin S. 2010. Konsep dan Masalah Pengajaran Ilmu Sosial Di sekolah Menegah. Jakarta: LPTK 